\title{
Mathematics Curriculum Reform and Its Implementation in Textbooks: Early Addition and Subtraction in Realistic Mathematics Education
}

\author{
Marc Van Zanten ${ }^{1,2, *(D)}$ and Marja Van den Heuvel-Panhuizen ${ }^{2,3}$ (D) \\ 1 Netherlands Institute for Curriculum Development, 3818 LE Amersfoort, The Netherlands \\ 2 Freudenthal Institute, Utrecht University, 3584 CS Utrecht, The Netherlands; \\ m.vandenheuvel-panhuizen@uu.nl \\ 3 Nord University, 8049 Bodø, Norway \\ * Correspondence: m.vanzanten@slo.nl or m.a.vanzanten@uu.nl
}

\section{check for} updates

Citation: Van Zanten, M.; Van den Heuvel-Panhuizen, M. Mathematics Curriculum Reform and Its Implementation in Textbooks: Early Addition and Subtraction in Realistic Mathematics Education. Mathematics 2021, 9, 752. https://doi.org/ $10.3390 /$ math 9070752

\section{Academic Editors: Alexander}

Maz Machado and María José Madrid Martín

Received: 3 March 2021

Accepted: 24 March 2021

Published: 31 March 2021

Publisher's Note: MDPI stays neutral with regard to jurisdictional claims in published maps and institutional affiliations.

Copyright: (c) 2021 by the authors. Licensee MDPI, Basel, Switzerland. This article is an open access article distributed under the terms and conditions of the Creative Commons Attribution (CC BY) license (https:// creativecommons.org/licenses/by/ $4.0 /)$.

\begin{abstract}
Since the late 1960s, a reform in mathematics education, which is currently known under the name Realistic Mathematics Education (RME), has been taking place in the Netherlands. Characteristic for this approach to mathematics education is that mathematics is not seen as ready-made knowledge but as an activity of the learner. Although much has been written about the big ideas and intentions of RME, and multiple RME-oriented textbooks have been published, up to now the development of this approach to mathematics education has not been thoroughly investigated. In the research reported in this article, we traced how RME has evolved over the years. The focus in our study was on early addition and subtraction in primary school. For this, we studied RME core curriculum documents and analyzed RME-oriented textbooks that have been published between the onset of RME and the present. We found that the big ideas and teaching principles of RME were clearly reflected in the learning facilitators for learning early addition and subtraction and were steadily present in curriculum documents over the years, although some were made concrete in further detail. Furthermore, we found all RME learning facilitators also to be present in all RMEoriented textbooks, though in some cases in other ways than originally intended. Our research shows the complexity of a curriculum reform process and its implementation in textbooks.
\end{abstract}

Keywords: mathematics curriculum reform; Realistic Mathematics Education; primary school; textbooks; early addition and subtraction

\section{Introduction}

Making decisions about what and how to teach forms the core of teaching mathematics. At a general level, the leading resource for making these decisions is the intended curriculum, which includes the aims, goals, and intentions of education [1,2]. At school level, guidelines for making decisions about these activities and eliciting the required learning processes can in particular be found in textbooks. These often serve as the main resource for the daily lessons in classrooms [3]. Since textbooks form an intermediate layer between the intended curriculum and the implemented curriculum, they are considered the potentially implemented curriculum [1]. Ideally, the intended and the potentially implemented curriculum are closely aligned with each other, but this is not self-evident. Several studies have shown examples of lacking coherence between these curriculum levels in mathematics education [4-6]. There are numerous factors that can cause differences between the intended and the potentially implemented curriculum, such as interpretations of goals, aims, and intentions by textbook authors, and commercial considerations from publishers.

Furthermore, the intended curriculum itself can be subject to change. Decisions regarding what is intended are largely based on what is believed to be good education 
and these beliefs are not a fixed given. Ideas on what mathematics should be taught and how this could be taught best, can differ significantly between countries [7,8]. Moreover, within countries, seen over time, new views on mathematics education can emerge and approaches to teaching mathematics can change [9-11].

The Netherlands too, has a history of mathematics education reform. Starting in the late 1960s, under guidance of the mathematician Hans Freudenthal, an approach to mathematics education has been developed, which over time became known as Realistic Mathematics Education (RME) [12]. Although much has been written about the intentions and ideas of RME, and publishers have released multiple RME-oriented textbooks, up to now the development of this approach to mathematics education has not been thoroughly researched. In fact, little is known about how particular RME ideas on the what and how of teaching mathematics have evolved in the past half century. The same can be said about how the RME reform can be found in textbooks. After the study "Wiskobas in methoden" (Wiskobas in textbooks) in the 1980s [13], no other systematic research has been carried out to investigate this.

The purpose of the current research was to contribute to closing this knowledge gap, to trace how the RME reform evolved, and to unravel the relationship between the intentions of the RME reform and its implementation in textbooks. To this end, we studied RME designs and their underlying ideas from the onset of RME up to the current day, and we examined how these designs and ideas ended up in textbooks over the years. To clearly bring into view the in-depth characteristics of RME as they are laid down in instructional materials, we focused on one key primary school mathematics domain: early addition and subtraction.

\section{Background of the Study and Research Questions}

\subsection{The Origin of $R M E$}

In the late 1950s, a need was felt in many western countries for "radical changes and improvements in the teaching of mathematics" [14] (p. 11). There were many reasons for this, varying from the increasing importance of mathematics and its applications for society to new insights on learning and teaching mathematics $[15,16]$. The case and proposals for reform were addressed at the conference held at the Centre Culturel de Royaumont in Asnière-sur-Oise (France) in 1959 [14]. This conference was the commencement of the world-wide impact of the New Math reform movement $[15,17]$. In the Netherlands however, under guidance of the "leading dissident" Freudenthal [18] (p. 1495), New Math would not gain a foothold. Instead, another direction was chosen, which eventually led to RME [19].

As a consequence of the Royaumont conference, in 1961 the Dutch government installed the Commissie Modernisering Leerplan Wiskunde (Commission Modernization Mathematics Curriculum) (CMLW), of which Freudenthal was a member and of which, in 1969, he became the chairman. The CMLW was commissioned to investigate what reform of content and didactics was needed in the Netherlands [20]. Originally, the focus was only on secondary education, but in 1968, with the establishment of the Wiskobas project as part of the CMLW, primary education also came into the picture. Wiskobas is an acronym for "wiskunde op de basisschool", which means "mathematics in primary school". The inception of the Wiskobas project marks the start of the development of RME. From 1971 on, the work of CMLW and Wiskobas continued in the newly founded Instituut voor Ontwikkeling van het Wiskundeonderwijs (Institute for Development of Mathematics Education), with Freudenthal as its first director. In 1991, the successor of this institute was renamed the Freudenthal Institute.

\subsection{The Big Ideas and Principles of RME}

Having a project named Wiskobas indicated a break with the past. Traditionally, in Dutch primary schools, mathematics as a subject was called "rekenen", i.e., arithmetic. Wiskobas wanted to bring a more mathematical perspective into primary education. 
Around 1970, the prevailing approach to arithmetic education in the Netherlands was rather mechanistic [21,22]. It had a characteristic focus on teaching fixed procedures in a step-by-step manner, with the teacher demonstrating how to proceed in each step. Real-world problems were only used for the application of previously learned calculation procedures, and little or no attention was paid to developing insight into the underlying mathematics of these procedures $[12,13]$. New Math was not considered a suitable alternative. In the words of Freudenthal [23] (p. 141), New Math took "the wrong perspective [...] of replacing the learner's insight by the adult mathematician's insight." The mathematics that Wiskobas had in mind was of another nature, namely, mathematics as an activity of the learner. Freudenthal $[24,25]$ considered mathematics as an activity instead of as ready-made knowledge. The latter refers to the already created system of mathematics of which Freudenthal [25] said that students, when it is offered to them, can only reproduce it. For him, in the first place, mathematics means mathematizing reality. Therefore, in his view, mathematics education should not be about transmitting ready-made mathematics to students, but about the activity of mathematizing [23].

This big idea of mathematics as the human activity of mathematizing became an important notion underlying the work of Wiskobas and the further development of RME. Treffers, one of the leading persons in the development of RME, later on made the distinction between horizontal and vertical mathematizing. Horizontal mathematizing refers to transforming real-world problems into mathematical terms, whereas vertical mathematizing refers to using mathematical means to solve the problems, generalizing the solution process, and achieving a higher level of formalization [22].

In RME, reality is seen as a starting point for learning processes. This important role of reality is expressed in the term "realistic". However, in RME, realistic also has a broader connotation. As well as using reality as a source for mathematics education, it refers to the Dutch verb "zich realiseren", which means to realize and to imagine what is going on [26-29]. In RME, students are offered problems which they can imagine, including problems from the fantasy world of fairy tales and the formal world of mathematics. Providing students with such problems implies a proactive role of the teacher, which is expressed in Freudenthal's other big idea [30], guided reinvention. According to Freudenthal the "re" in reinvention refers to the steps in learning processes, while the adjective "guided" points to the instructional environment of the learning processes. Guiding reinvention implies a balance between, on the one hand, letting students think and invent things, and on the other hand providing guidance that provokes reflective thinking. Treffers [22] underlined this view by emphasizing that students' own constructions and own productions have a decisive influence on the learning process. According to him, stimulating students to come up with self-made solutions when solving problems or making up problems themselves is a crucial element of RME and "the basis of everything" [31] (p. 72).

These big ideas of RME ("the human activity of mathematizing" in connection with "horizontal and vertical mathematization" and "guided reinvention" in connection with "own constructions and own productions") that stem from the work of Wiskobas have been repeatedly formulated and specified in different ways. Treffers [21,22] characterized the Wiskobas approach in eight starting points, which included three didactical principles (activity, differentiation, and vertical planning) and five mathematical principles (structure, language, applicability, dynamics, and a specific approach), which he summarized in his 1987 publication as the four starting points of realistically oriented mathematics education: paying much attention to reinvention, various levels of concreteness and abstraction, historical-genetic (vertical) planning, and reality-bound, meaningful (mathematically rich) instruction. Additionally, Treffers [22] defined five instruction principles that guide progressive mathematizing: phenomenological exploration, bridging by vertical instruments, self-reliance: students' own constructions and productions, interactivity, and intertwining. In a later publication [32], these instruction principles were reformulated as the five fundamental learning principles of the reconstruction didactics: constructing and con- 
cretizing, levels and models, reflection and own production, social context and interaction, structuring, and intertwining.

The beginning years of RME were clearly ones of continuously reconceptualizing what the reformed mathematics education stood for. Several starting points and principles had much in common but were reworded from time to time. Van den Heuvel-Panhuizen [33] summarized these RME characteristics and identified the following six principles: the activity, the reality, the level, the intertwinement, the interactivity, and the guidance principle. We follow these principles here. The activity principle refers to the concept of mathematics as a human activity. Students, instead of being the receivers of ready-made mathematics, are treated as active participants in the learning process in which they are stimulated to develop mathematical tools and insights. The reality principle emphasizes that learning mathematics is considered as originating in mathematizing reality. This means starting from meaningful, mathematically rich context situations, which offers opportunities to attach meaning to mathematical concepts. The level principle underlines that learning mathematics implies that students pass through various levels of understanding: from starting at the level of using informal context-related solutions, via making various shortcuts and schematizations, to being able to use formal procedures. Models serve as an important device for bridging between concrete situations and formal mathematics. The intertwinement principle means that related learning strands are taught in integration. The interactivity principle signifies that learning mathematics is not only an individual activity but also a social one. Through whole-class discussions and group work, students can learn from each other's strategies and insights. The guidance principle signifies the importance of offering students a guided opportunity to re-invent mathematics. In RME, the teachers, supported by long-term teaching-learning trajectories and textbooks, have a crucial role in steering the learning process by providing the students with a learning environment which enables that they can develop mathematical understanding.

\subsection{RME and Textbooks}

Over the years, RME has made a considerable impact on the textbook market in the Netherlands. Periodic studies by Cito, the Dutch institute for educational measurement, indicate an increasing market share of RME-oriented textbooks from around 15 percent in the mid-1980s to 75 percent in the 1990s [34] and further to 100 percent around 2003 [35].

After 2007, due to a debate criticizing the RME approach in favor of a return to the traditional mechanistic approach [36,37], the textbook market became more diverse again [38]. Moreover, new editions of textbooks that were originally presented by their publishers as RME-oriented, were no longer labeled as such. Of course, the approach to mathematics education that is attributed to a textbook does not tell the whole story. Textbooks that are no longer presented as RME-oriented may still include RME characteristics, just as textbooks positioned as RME-oriented do not necessarily include all RME features.

The latter was demonstrated by De Jong [13] in his study "Wiskobas in methoden". He analyzed textbooks in use from 1970 to 1985 and found that not all textbooks that were presented by their authors or publishers as based on Wiskobas could actually be classified as such. His study showed a steadily growing market share of textbooks that included RME characteristics, but also revealed that these characteristics rather varied in their degree of alignment with the intentions as articulated by Wiskobas at that time. Since the De Jong's study, no more research has been carried out to investigate how RME-oriented textbooks are in line with the original ideas of RME.

\subsection{Research Questions}

In addition to what is known from De Jong's study, no other knowledge is available regarding the relationship between the intentions of RME and its implementation in textbooks. The aim of the current research was to get a more complete and up-to-date view on this relationship, taking into account both the original ideas of Wiskobas and the evolvement of RME ideas since that time period. This implied that we had to carry out two 
studies: a study into the intentions in Wiskobas and RME and their evolvement over time, and a study into how, from the Wiskobas years to the present, these intentions ended up in RME-oriented textbooks.

To investigate this on a detailed level, we focused on one domain of primary school mathematics: early addition and subtraction. We chose this domain for two reasons. First, it is a core domain of mathematics that serves as a basis for all other primary school mathematical domains. Second, in the Wiskobas time, this domain was worked on from the very beginning, which gave us the opportunity to investigate how the approach to this domain evolved within RME. Our research questions for the respective studies were:

1. How did the RME approach on early addition and subtraction evolve? (Study 1)

2. How was the RME approach on early addition and subtraction implemented in consecutive generations of RME-oriented textbooks? (Study 2)

We specified "early addition and subtraction" as: addition and subtraction in the lower grades of primary school, from the moment that these operations are introduced, and before written algorithmic calculation is introduced.

In both studies we answered the research questions by document analyses. In Study 1 we choose RME curriculum documents for this and in Study 2 we analyzed RME-oriented textbook series.

\section{Study 1: The RME way of teaching early addition and subtraction as intended}

\section{Method Study 1}

\subsection{Selection of RME Documents}

To answer our first research question, we analyzed the core RME curriculum documents that address early addition and subtraction. These documents are:

- the first Wiskobas overview of primary school mathematics education published in 1975 [39]: Part 1: Scenes of mathematics education in the lower grades, pp. 13-120;

- "Proeve van een nationaal programma voor het reken-wiskundeonderwijs op de basisschool" (Design of a national program for mathematics education in primary school) (hereafter called Proeve), published in 1990 [40]: Part 1: Basic operations pp. 9-173;

- $\quad$ the TAL (Teaching and learning trajectory) document meant for teaching mathematics in the lower grades of primary school, published in 1999 [41] which has also been published in English [42]: Calculation up to 20 and Calculation up to 100, pp. 43-74.

\subsection{Analysis Procedure}

In our analysis, we first detected all suggestions that these documents offer for facilitating the learning of early addition and subtraction. We classified these suggestions into categories of learning facilitators based upon the big ideas and principles of RME. These categories are (1) the use of reality, (2) the use of models, (3) the use of students' own input, and (4) the use of non-routine problems. Finally, we compared and related the suggested learning facilitators and their intended use to each other and created a chronological overview.

\section{Results Study 1}

\subsection{Use of Reality}

In the Wiskobas document, addition and subtraction are introduced by using the bus context as the reality-related starting point. This means that the students play a bus game. One student acts as the bus driver and the other students are the passengers. At bus stops situated throughout the classroom students get on and off the bus, which gives them a first meaning for addition and subtraction. The students keep track of how many passengers get on and off the bus and how many are on the bus after a bus stop. From the beginning on, one situation is used for carrying out multiple calculations. Further, addition and subtraction are introduced simultaneously. This arises naturally from the fact that people 
can get both into and out of a bus. Figuring out what happens gives students opportunities for mathematical reasoning:

"What may have happened, when the bus drives away from the bus stop with three passengers more than it arrived with? Did three passengers get on or did perhaps five people get on and two off the bus?" [39] (p. 36).

After the physical experiences of the bus game, similar situations are also presented on worksheets (Figure 1).

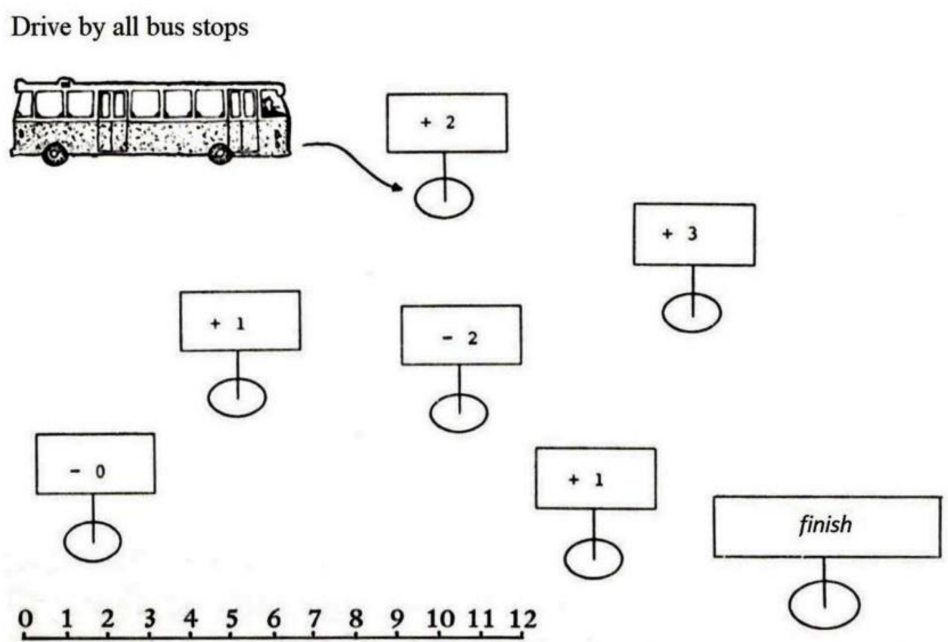

Figure 1. The bus context in Wiskobas. [39] (p. 41).

Directly at the start, arrow language is used as a symbolic representation that refers to reality. It is used to let students describe that "something is happening" [39] (p. 39). They have to put into words what is happening in a situation and write this down in arrow language. They do so in all kinds of situations, which provides them with multiple meanings of addition and subtraction. Moreover, interpreting particular situations in different ways underlines the relationship between addition and subtraction (Figure 2).

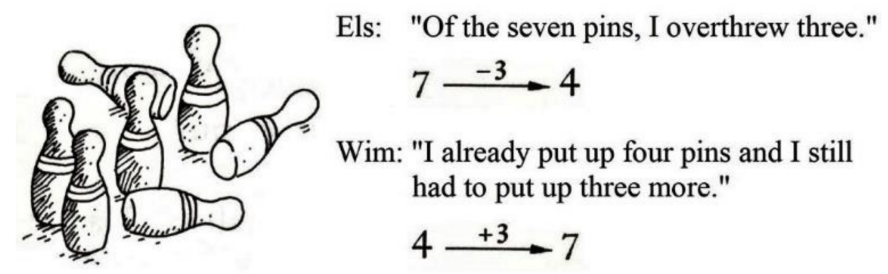

Figure 2. Arrow language in Wiskobas [39] (p. 40).

The Proeve document does not address the initial introduction of addition and subtraction and does not mention the bus context. However, Proeve makes it clear that to develop understanding of addition and subtraction, students have to be provided with varied context situations. Arrow language is used to express what is happening in these context situations, but Proeve does not suggest letting students write down arrow language, nor to use it to relate addition and subtraction.

In TAL, various context situations are used for giving meaning to addition and subtraction, including the bus context. Addition and subtraction are not jointly introduced in one situation. Carrying out multiple calculations in one particular situation is also not described. Arrow language is mentioned for expressing what is happening in a situation.

\subsection{Use of Models}

The core documents describe several models. The most prominently present are the number line, the one hundred square and the arithmetic rack. 
The number line that is used in Wiskobas is segmented. This number line is introduced for calculations beyond ten, when students experience that counting on their fingers is no longer sufficient. The segmented number line is used to support calculating by counting and moving forward (for addition) and backward (for subtraction). It is also used for positioning numbers, which means identifying where particular numbers are located (Figure 3). Furthermore, in combination with bars, it is used for laying the relationship between addition and subtraction (Figure 4).

Put the numbers at the right spot

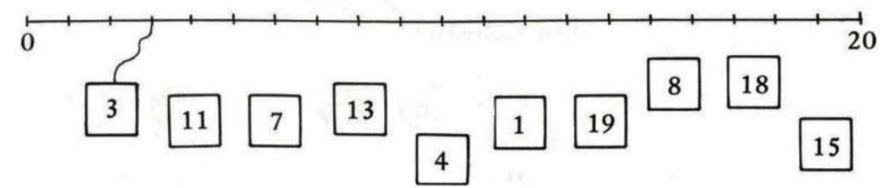

Figure 3. Positioning numbers on a segmented number line in Wiskobas [39] (p. 40).

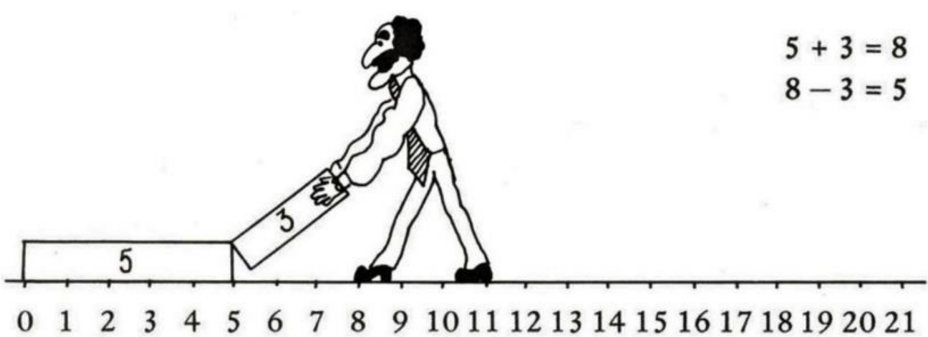

Figure 4. Relating addition and subtraction on a segmented number line in Wiskobas [39] (p. 88).

In Proeve and TAL, the number line has a different appearance: it is now an empty number line. It is emphasized that a number line with no or only a few marked points stimulates the use of number relations (e.g., 19 is near 20 and 10 is in the middle between 0 and 20). To introduce this number line, both documents suggest a string of beads. The alternating pattern of colors (Figure 5, above) provides students with a ten-structure, which helps them to apply shortened counting with tens. A pin placed on the bead string indicates the number of beads before that particular point. This representation of numbers is also used for the empty number line (Figure 5, below).

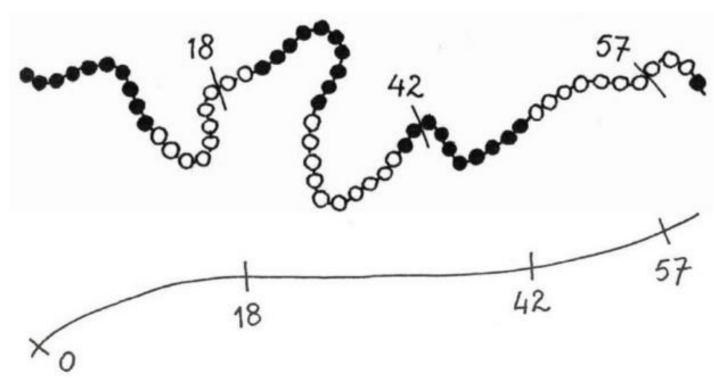

Figure 5. The bead string and the empty number line in Proeve ([40] (p. 51-52).

In Proeve and TAL, the empty number line is also applied for acting out variouslystructured calculation procedures to solve addition and subtraction problems. For example, the subtraction 65 - 38 can be calculated by stringing, first by making jumps of ten, (65 $-10-10-10-8$, Figure 6a) and later by making fewer jumps (e.g., $65-30-5-3$, Figure 6b). Moreover, varying strategies are possible, such as a shortened approach via a nearby round number $(65-40+2$, Figure $6 c)$ or an adding on strategy $(38+\ldots=65$, Figure 6d). This latter strategy is the only case in Proeve and TAL in which the relationship between addition and subtraction is brought to the fore. 
a.

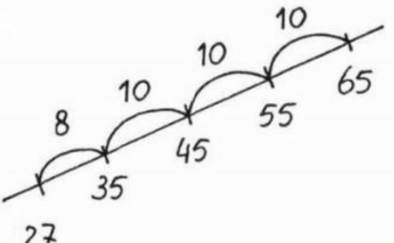

c.

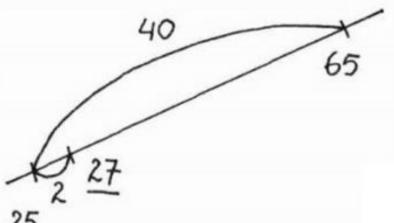

b.

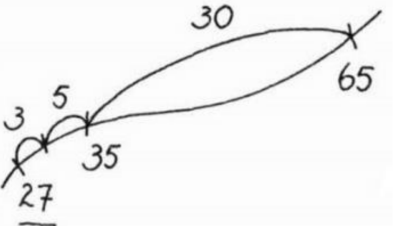

27

d.

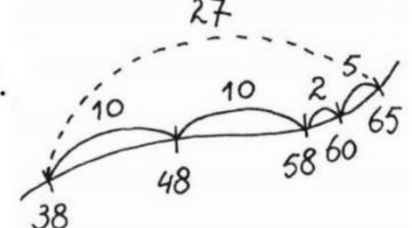

Figure 6. Calculating $65-38$ on the empty number line by doing (a) $65-10-10-10-8$, (b) $65-30-$ $5-3$, (c) $65-40+2$ and (d) $38+\ldots=65$ in Proeve [40] (p. 54-55).

Proeve also describes the splitting strategy in which the tens and ones are processed separately (e.g., $27+38$ calculating as $20+30$ and $7+8$ ). For this strategy, not the number line, but 10-blocks and 1-blocks are suggested. TAL turns away from the decimal splitting strategy and suggests not to emphasize it because it can easily lead to mistakes in the case of subtraction.

The second model is the one hundred square. This is a ten-by-ten frame in which the numbers 1 to 100 are placed. In Wiskobas, this model is a kind of extension of the segmented number line up to 100 (Figure 7). The one hundred square can be used completely or partly filled with numbers, and as both the whole square and fragments. It is employed for all kinds of exploratory activities (Figure 8 ) and for practicing addition and subtraction by moving on the square. For example, three steps to the left mean subtracting three and two steps downward represent adding twenty.

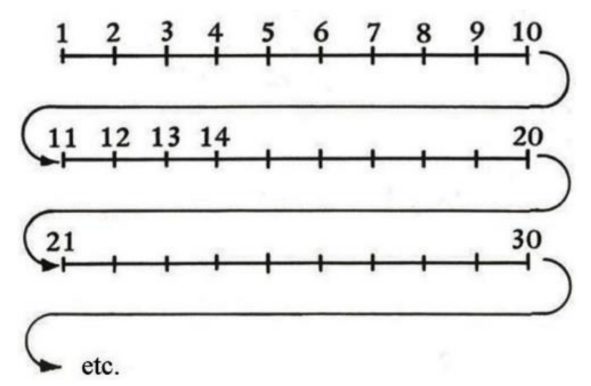

Figure 7. The one hundred square as an extension of the number line in Wiskobas [39] (p. 60).

Put these parts at the right place on the empty one hundred square

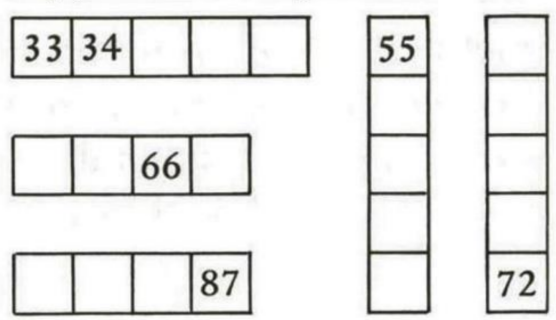

Figure 8. An exploratory activity with the one hundred square in Wiskobas [39] (p. 61).

In Proeve, it is said that the one hundred square is hard to understand and to use for many children. One reason that is mentioned is that jumps of one (to the right or left) and jumps of ten (downward or upward) on the one hundred square look as if they 
have the same value (each is a move of one cell), while in fact they have not. In TAL, the one hundred square is largely absent. It is mentioned only once as a model to represent numbers, and it is argued to be not very suitable to use for addition and subtraction.

The third model is the arithmetic rack for addition and subtraction up to twenty. This arithmetic rack, in Dutch called "rekenrek", has two lines of ten beads, each divided in two sets of five beads. This model is mentioned for the first time in Proeve (Figure 9). It is meant for structuring numbers using the five-structure, ten-structure, and the doubles. These number representations can help students to shift from calculation by counting to calculation by structuring. Proeve describes the example of $6+7$, which can be put on the arithmetic rack as shown in Figure 9. Students can derive the answer from seeing the five and five, which makes ten, and adding one and two, making thirteen $(5+5=10$ and then $10+1+2=13)$. Another way is seeing the double six and adding one $(6+6=12$ and then $12+1=13)$. Furthermore, they can calculate via ten $(6+4=10$ and then $10+3=13)$. The arithmetic rack is considered an important model because "it allows flexible use of multiple solution procedures, while at the same time offering fixed number images that facilitate memorizing calculations up to $20^{\prime \prime}[40]$ (p. 48). In TAL, the arithmetic rack is used for structuring numbers and for addition and subtraction up to twenty in the same way as in Proeve.

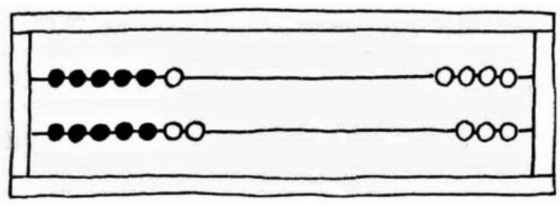

Figure 9. The arithmetic rack in Proeve [40] (p. 45).

\subsection{Use of Students' own Input}

In Wiskobas, the use of students' input in the teaching-learning process comes to the fore in two ways. The first one is the already mentioned emphasis on letting students explain in their own words what is happening in context situations and writing this down with arrow language. The second way is to ask students to produce their own problems, such as thinking of a route for the bus that results in a specific number of passengers in the end.

Proeve also emphasizes having students putting into words what is happening in context situations. In addition, the students are asked to explain their acting in words while carrying out calculations. Moreover, it is emphasized to give students ample opportunities to come up with their own calculation procedures, and to make use of these own constructions as a basis for shortened and structured solution procedures. This can be done, for example, by using the arithmetic rack and the empty number line that allow various solution strategies, as described in the section about models. Inviting students to come up with own productions (i.e., thinking of problems with a particular answer) is also present in Proeve.

TAL emphasizes that letting students use their own wordings is important in all phases of the teaching-learning process, including letting students explain and compare their own constructed and used solution procedures. Furthermore, using students' own productions is stretched into a form of practicing addition and subtraction, for which the term "productive practice" [42] (p. 52) is used.

\subsection{Use of Non-Routine Problems}

Wiskobas suggests asking students questions that require more than only straightforward calculation but instead evoke reflection and reasoning. The earlier mentioned question about what may have happened when the bus drives away from the bus stop with three passengers more than it arrived with is an example of this. Another example concerns the context of a double-decker bus, in which some passengers take a seat on the lower level of the bus and others on the top level. This context is used for splitting numbers 
(a prerequisite skill for addition and subtraction) and it is suggested to ask students to figure out whether they have found all possible splittings for a particular number. Answering this question requires a systematic approach and mathematical reasoning.

In Proeve, it is stated that providing non-stereotype problems from time to time is important to prevent students from routinely guessing what operation to apply instead of consciously reasoning for themselves. An example is

"Two friends celebrate their birthday together. Without consulting each other, they each invite their friends. One invites five friends and the other invites six. How many friends are invited?" [40] (p. 157).

Finally, TAL provides examples of non-routine, puzzle-like problems that combine problemsolving with practicing calculations and emphasizes to use such problems on a regular basis.

\section{Conclusions Study 1}

Study 1 revealed both differences and similarities in the intended RME approaches on early addition and subtraction as laid down in the analyzed core curriculum documents. A summarizing visualization of our findings is shown in Table 1.

The three curriculum documents correspond on the use of context situations to provide meaning to addition and subtraction. In Wiskobas and TAL, this includes the bus context. In Wiskobas, this context is used for the simultaneous introduction of addition and subtraction and for carrying out multiple calculations in one situation. Arrow language is suggested in all three documents for symbolizing what is happening, and in Wiskobas also for letting students write it down and for relating addition and subtraction.

The documents differ remarkably regarding the models suggested. The one hundred square is explicitly promoted in Wiskobas, but no longer recommended in Proeve, and finally, TAL suggests not to use it. The number line evolved from a segmented line in Wiskobas to an empty line in Proeve and TAL. This has significant implications. On the segmented number line, positioning numbers and making calculations can be done by simply counting the tick marks, while the empty number line evokes the use of number relations and of shortened and structured calculation procedures. The arithmetic rack is not yet present in Wiskobas, but it has a prominent role in Proeve and TAL. This model and the empty number line are both used for level-raising by supporting structured calculation. Both also allow a variation of calculation procedures which is helpful for the idea of using students' own constructions of solution procedures as introduced in Proeve. The other ways of using students' own input-letting students put into words what is happening and come up with their own productions of problems-are present in all three documents. The same applies to the use of non-routine problems that evoke reflection and reasoning.

A final finding concerns the relationship between addition and subtraction, which reflects the RME intertwinement principle. Only Wiskobas suggests ways to connect the two operations, namely by use of the bus context, arrow language and the segmented number line. The relationship between addition and subtraction is not entirely absent in Proeve and TAL. They both discuss that some subtraction situations can easily be solved by an adding-on strategy, but they do not put an explicit emphasis on the relationship between addition and subtraction. 
Table 1. Realistic Mathematics Education (RME) learning facilitators and their intended use for early addition and subtraction as indicated in Wiskobas $(\mathrm{W})$, Proeve (P), and TAL (T).

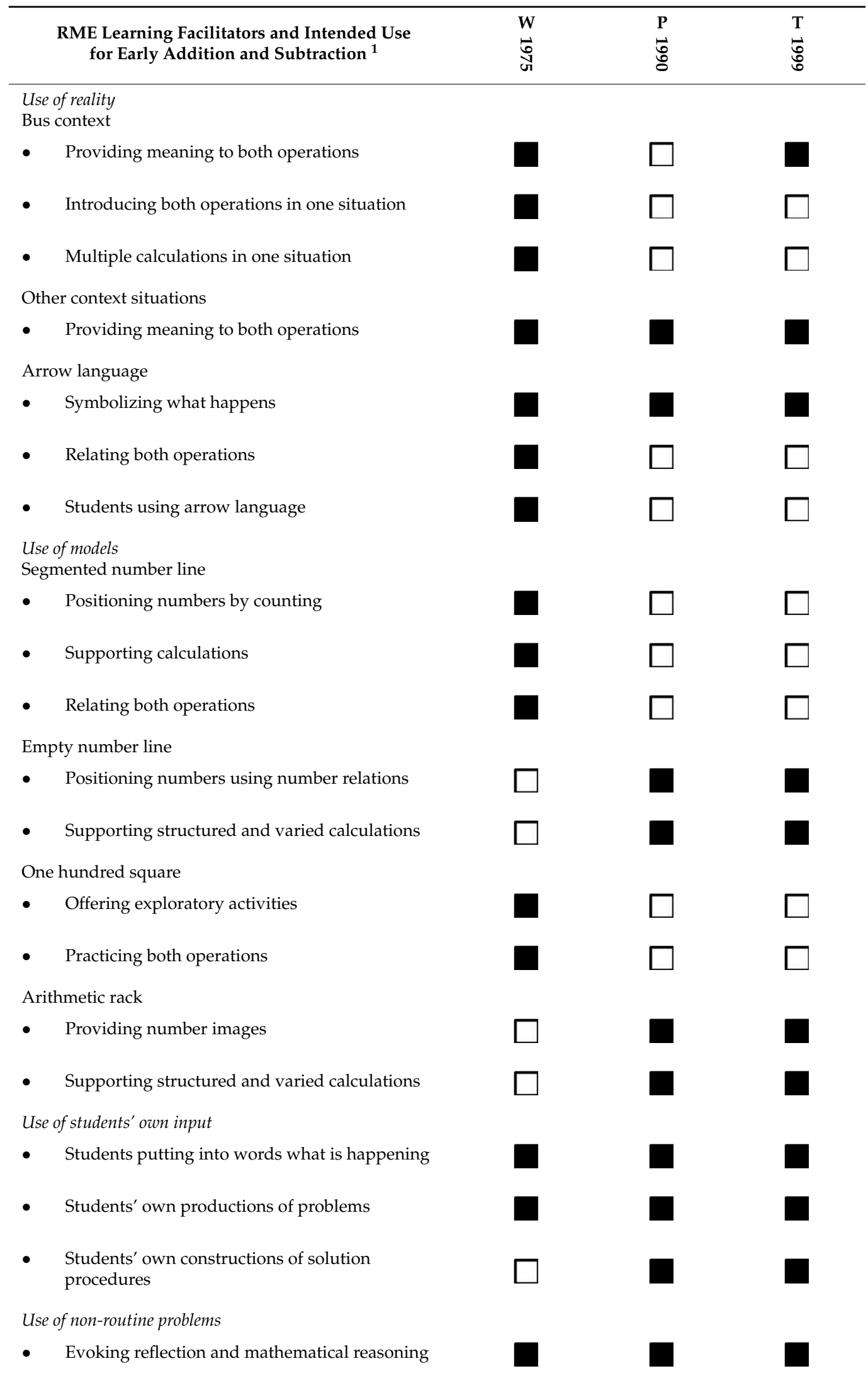

${ }^{1}$ Note: $\mathbf{\square}=$ present, $\square=$ absent 
To conclude Study 1, the answer to our research question on the evolvement of the RME approach on early addition and subtraction as intended is threefold. First, the categories of learning facilitators based upon the big ideas and teaching principles of RME are steadily present in all analyzed documents. Second, some of the learning facilitators were made concrete in further detail over the years. This especially comes to the fore in the use of the arithmetic rack and the empty number line which both provide opportunities for structured solution procedures and make way for using students' own constructions of varied calculation strategies. Third, another remarkable change concerns the intertwinement of addition and subtraction, which is only emphasized in Wiskobas and no longer in Proeve and TAL.

Study 2: The RME way of teaching early addition and subtraction as implemented in textbooks

To answer the second research question, we investigated how the intended RME approach to teaching early addition and subtraction—as established in Study 1-has been implemented in textbooks over the years. To this end, we carried out an analysis of RME-oriented textbook series.

\section{Method Study 2}

\subsection{Selection of Textbook Series}

The selection of textbook series to be included in our study was based on two criteria. First, the design of a textbook should be intentionally RME-oriented, evidenced by making explicit references to Wiskobas or RME in teacher guidelines or information brochures. Textbooks that are adapted versions of textbooks from other countries or that are based upon other didactical approaches may have some RME characteristics but were not included in our study. The second criterion concerns the market share. Since a larger market share is an indication of a greater acceptance of a textbook by teachers, we only included textbooks that reached a fifteen percent market share or more and their successive editions. For determining the market share, we used information from the evaluation studies that Cito carried out between 1986 and 2013 and oral information from publishers and sellers of textbooks. The two criteria combined resulted in a collection of thirteen (editions of) textbook series in use from the 1980s on until today: five consecutive editions of "De Wereld in Getallen" (WiG1, WiG2, WiG3, WiG4, WiG5) (The World in Numbers), four editions of "Pluspunt" (PP1, PP2, PP3, PP4) (Plus Point), the textbook series "Rekenen \& Wiskunde" $(\mathrm{R} \& W)$ (Arithmetic and Mathematics) and its successor "Wis en Reken" (W\&R) (Certainty and Calculate), and two editions of "Rekenrijk" (RR2, RR3) (Rich Arithmetic/Realm of Arithmetic) (Table 2). The two 1980s textbooks were also included in the previously mentioned study "Wiskobas in Methoden" [13], in which it was concluded that these textbooks were highly aligned to the ideas of Wiskobas.

\subsection{Selection of Textbook Materials}

We selected from each textbook series the materials for the grade levels in which early addition and subtraction are taught. These are grades 1 and 2 in the 1980s textbooks and grades 1, 2, and 3 in the textbooks from the later time periods. The two textbooks published in 2019 introduce addition and subtraction already in K2, but these parts of the textbooks were not yet on the market when Study 2 was conducted and could therefore not be included in our analysis. 
Table 2. Textbook series included in Study 2.

\begin{tabular}{|c|c|c|c|c|}
\hline Time Period ${ }^{1}$ & Name & Abbr. & Publication Year & Market Share $^{2}$ \\
\hline \multirow{2}{*}{$1980 \mathrm{~s}$} & $\begin{array}{l}\text { De Wereld in Getallen, } \\
\text { 1st edition }\end{array}$ & WiG1 & 1981 & $28 \%$ \\
\hline & Rekenen \& Wiskunde & $\mathrm{R} \& W$ & 1983 & $29 \%$ \\
\hline \multirow{2}{*}{$1990 \mathrm{~s}$} & $\begin{array}{l}\text { De Wereld in Getallen, } \\
\text { 2nd edition }\end{array}$ & WiG2 & 1991 & $19 \%$ \\
\hline & Pluspunt, 1st edition & PP1 & 1991 & $29 \%$ \\
\hline \multirow{4}{*}{$2000 \mathrm{~s}$} & $\begin{array}{c}\text { De Wereld in Getallen, } \\
\text { 3rd edition }\end{array}$ & WiG3 & 2001 & $30 \%$ \\
\hline & Pluspunt, 2nd edition & PP2 & 2000 & $55 \%$ \\
\hline & Wis en Reken & W\&R & 2000 & $7 \%$ \\
\hline & Rekenrijk, 2nd edition & RR2 & 2000 & $16 \%$ \\
\hline \multirow{3}{*}{$2010 s$} & $\begin{array}{c}\text { De Wereld in Getallen, } \\
\text { 4th edition }\end{array}$ & WiG4 & 2009 & $50 \%$ \\
\hline & Pluspunt, 3rd edition & PP3 & 2009 & $25 \%$ \\
\hline & Rekenrijk, 3rd edition & RR3 & 2009 & $5 \%$ \\
\hline \multirow{2}{*}{ current } & $\begin{array}{c}\text { De Wereld in Getallen, } \\
5 \text { th edition }\end{array}$ & WiG5 & 2019 & - \\
\hline & Pluspunt, 4th edition & PP4 & 2019 & - \\
\hline
\end{tabular}

${ }^{1}$ Decade in which the textbook was or is most used. ${ }^{2}$ Highest known or estimated percentage of schools that at some point in time used the textbook. Market share is not yet known for the two textbooks published in 2019.

All the textbook series consist of student material, including lesson books, work sheets and (from the 2000s on) software. They also all provide teacher guidelines, sometimes with additional user brochures, including daily lesson directions and background information. In our analysis, we incorporated all parts of these materials that provide information about the intended instructional approaches, from both the student and the teacher materials. These include the parts in which, according to the teacher guidelines, instruction and whole-class teaching are supposed to take place in the daily lessons, and information about teaching sequences and didactical directions provided in the guidelines and user brochures. Materials such as tests, materials for repetition and enrichment materials were left out of our analysis.

\subsection{Analysis Procedure}

We used the findings of Study 1 (Table 1) as a framework for the analysis of the textbooks. The focus was on use of reality, use of models, and use of students' own input. The use of non-routine problems was not included in our second analysis, because this is already extensively reported upon in other studies $[43,44]$.

The analysis contained two steps. First, we searched in the selected textbook materials for the presence of the RME learning facilitators. Next, we checked whether the use as indicated in the textbooks corresponds to the intended use according to the RME core documents. To ensure that no relevant information was overlooked and the correspondence with the RME approach was judged correctly, the search and the checking were done multiple times. The analysis was mainly carried out by the first author and findings were frequently discussed with the second author.

\section{Results Study 2}

The RME learning facilitators were found to be present in all the analyzed textbooks, but we also discovered multiple differences. For all analyzed textbook series, the findings are visualized in Table 3. 
Table 3. RME learning facilitators and their intended use for early addition and subtraction as included in RME-oriented textbooks.

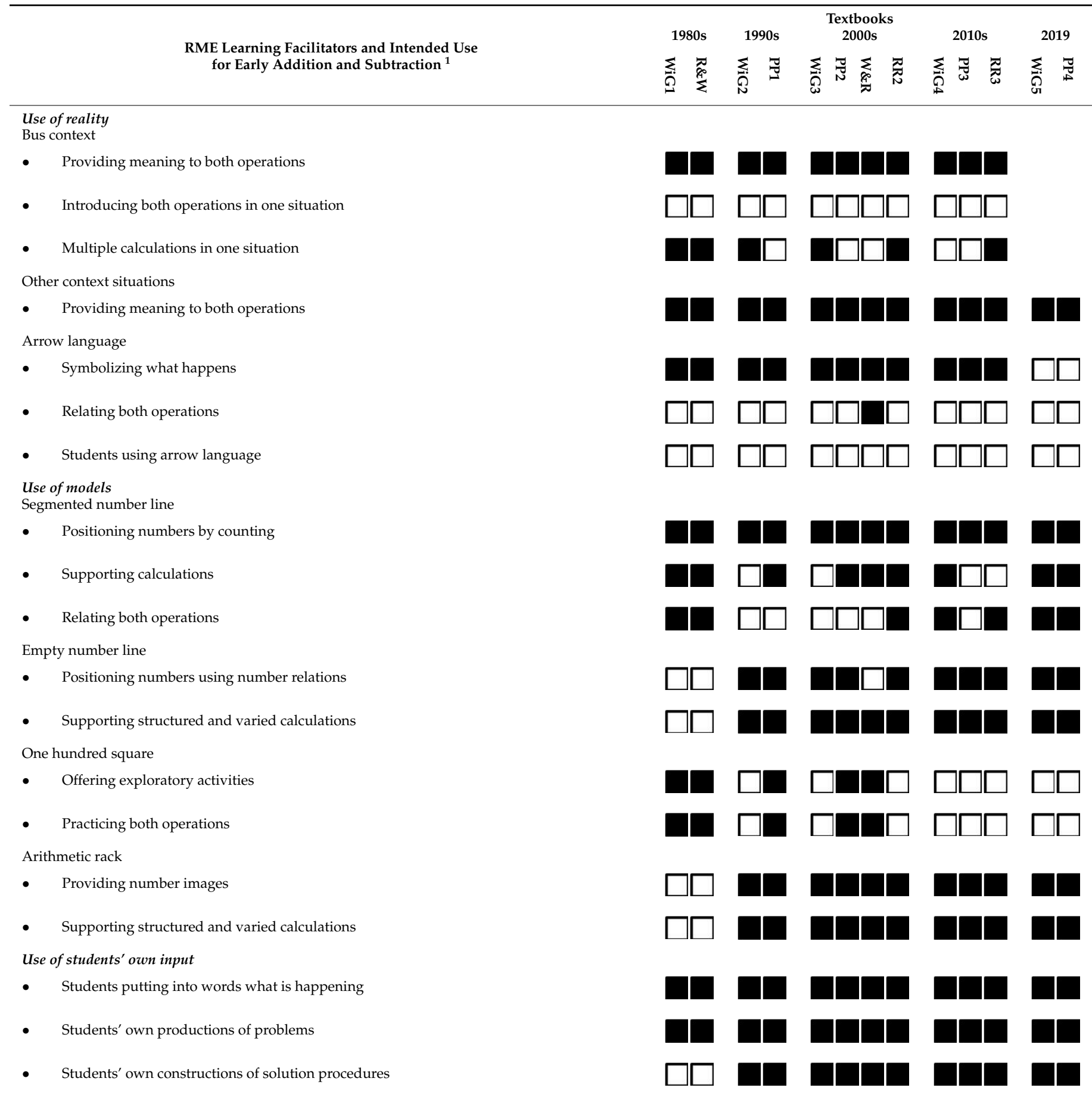

\footnotetext{
${ }^{1}$ Note: $\mathbf{\square}=$ present, $\square=$ absent.
}

\subsection{Use of Reality}

The eleven textbooks released from the 1980s to the 2010s all use the bus context to introduce addition and subtraction. In none of these textbooks do the operations take place simultaneously in one situation as suggested by Wiskobas. Some teacher guidelines state explicitly that only one thing happens at each bus stop: passengers are either getting on or off the bus. Regarding offering multiple calculations in one bus situation, the textbooks differ. The two 1980s textbooks include this, as well some textbooks in the following decades (WiG2, WiG3, RR2 and RR3), but the others do not. We were not able to establish 
whether the bus context is still used in the two textbooks published in 2019, since the kindergarten materials in which addition and subtraction are introduced in these textbook series were not yet available at the time of our analysis.

All thirteen textbooks offer varying other context situations, providing multiple meanings of addition and subtraction. In the textbooks released from the 1980s to the 2010s, this is also combined with arrow language. Regarding the use of arrow language, the interpretation in the textbooks differs from Wiskobas. In all these textbooks, arrow language is mainly offered as a ready-made fill-in exercise (Figure 10) in which students only have to add the missing numbers, and sometimes missing operation signs as well. Only very occasionally do students have to describe a problem situation by using arrow language, and when this is asked, the guidelines state that the teacher has to demonstrate each step. Furthermore, in only one textbook (W\&R) is arrow language used to relate addition and subtraction to each other. In the two textbooks published in 2019, arrow language is no longer used.

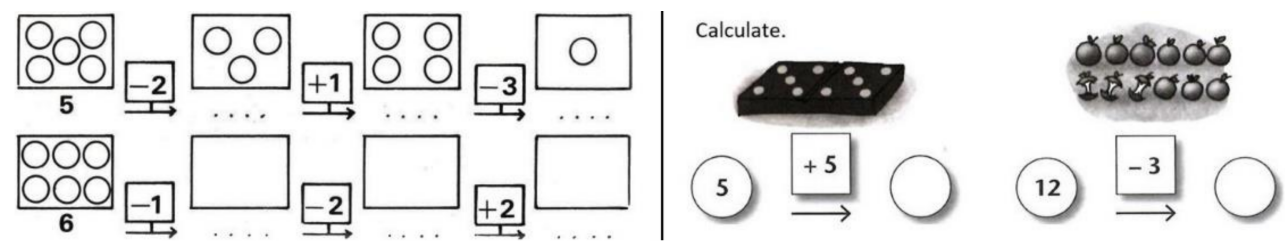

Figure 10. Arrow language in R\&W (1980s, left, Grade 1, student book 1-3, p. 50) and PP3 (2010s, right, Grade 1, student book 7-8, p. 46).

\subsection{Use of Models}

All thirteen textbooks provide the model of the segmented number line and use it for positioning numbers. The textbooks differ on other ways of using the segmented number line. Using it to relate addition and subtraction to each other is done in all the 1980s and the 2019 textbooks, and in three textbooks (RR2, RR3 and WiG4) from the intervening period. In the majority of textbooks, the segmented number line is used for supporting calculation. Some of these textbooks (W\&R, WiG4, WiG5 and PP4) provide the segmented number line only for calculations up to 20 and not to support calculations with larger numbers.

The empty number line is present in all eleven textbooks published from the 1990s on. All these textbooks but one (W\&R) use it to position numbers. This means that in most textbooks the positioning of numbers is supported both by the segmented and the empty number line. The bead string, which was introduced in Proeve together with the empty number line, is present in all but one (WiG2) of the textbooks that were published since then. In six textbooks (PP1, PP2, PP3, RR2, WiG3 and WiG4), the bead string is used to attach meaning to the empty number line, and in four textbooks (RR2, RR3, WiG5, and PP4) the bead string is (also) related to the segmented number line (Figure 11).

All eleven textbooks published from the 1990s on in which the empty number line is present use it to support structured and varied calculation procedures (Figure 12). They all offer the empty number line to support calculation by stringing (e.g., calculating $36+29$ by doing $36+10+10+4+5$ ) and by using varying strategies (e.g., $36+29$ by doing $36+30-1$ ). This use of the empty number line is consistent with Proeve and TAL. 


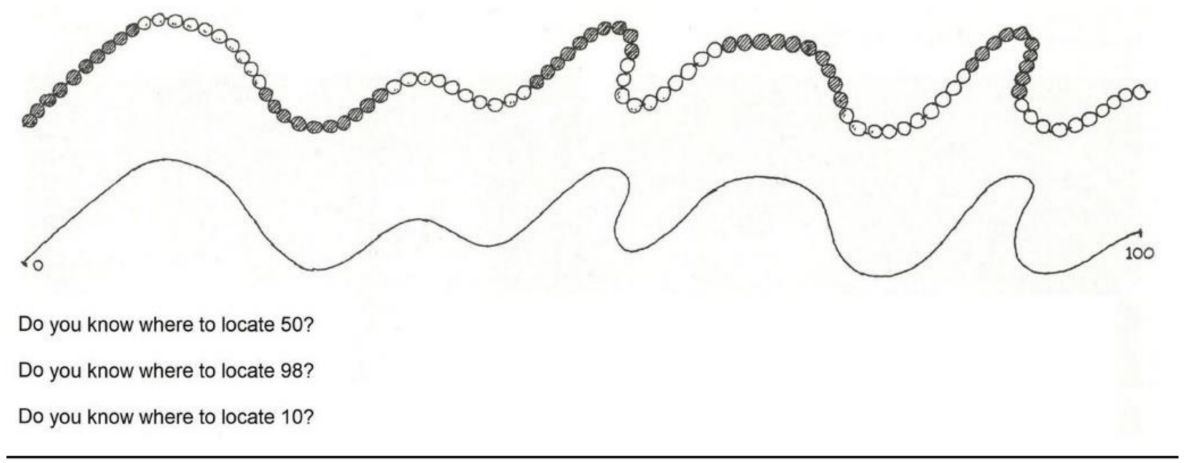

\section{Which number?}

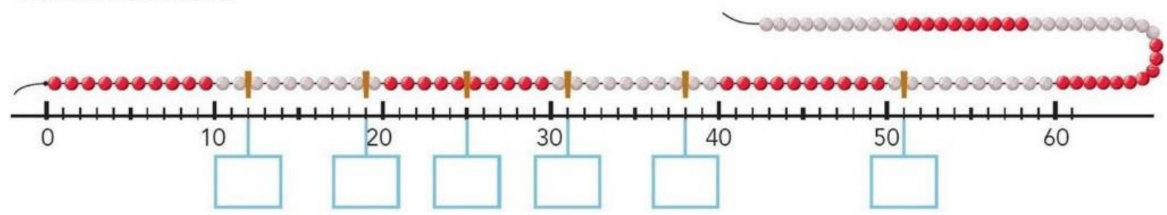

Figure 11. The number bead combined with the empty number line in PP1 (1990s, above, Grade 2, lesson book p. 57) and with the segmented number line in WiG5 (2019, below, Grade 1, student book 8, p. 4 [Reprinted with permission of Malmberg Publishers]).
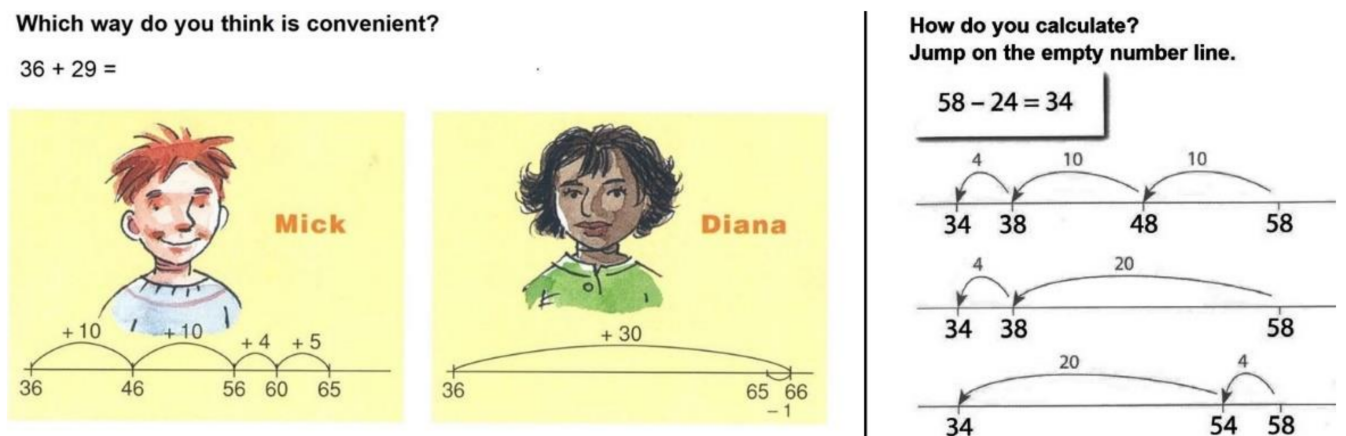

Figure 12. Stringing and varying calculation strategies on the empty number line in PP2 (2000s, left, Grade 3, lesson book p. 9) and WiG4 (2010s, right, Grade 2, student book p. 19).

For splitting procedures (e.g., $27+18$ by doing $20+10$ and $7+8$ ), the first three editions of WiG and the first two editions of PP use visualizations with 10-blocks and 1-blocks, which is also consistent with Proeve. Since the 2010s, this use of blocks is no longer present in textbooks.

The one hundred square is provided in both 1980s textbooks. In line with Wiskobas, this model is used for exploratory activities and for practicing calculations. This is also the case in one 1990s textbook (PP1) and two 2000s textbooks (PP2 and W\&R). From the 2010 textbooks on, the use of the one hundred square for early addition and subtraction has disappeared, which corresponds with Proeve and TAL.

The arithmetic rack is used in all eleven textbooks published from the 1990s on. All these textbooks use it for providing multiple number images and for replacing counting by structured addition and subtraction (Figure 13), which is both in line with Proeve and TAL. 
Use the pictures to calculate.
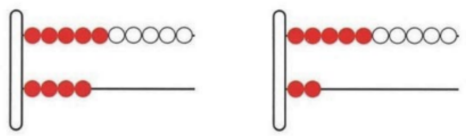

$14-5=$

$14-10=$

$14-7=$

$14-9=$

$14-8=$

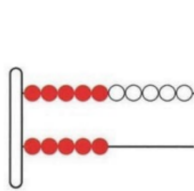

$15-10=$

$15-9=$

$15-7=$

$15-4=$

$15-6=$
Calculate via 10.

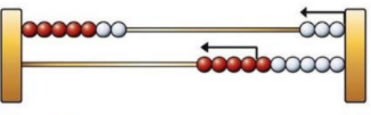

$7+7=$

Calculate with doubles.

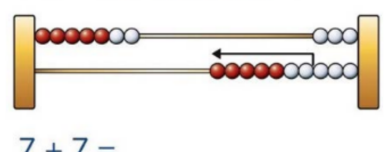

Figure 13. Calculating with the arithmetic rack in W\&R (2000s, left, Grade 2, student book 4, p. 14) and RR3 (2010s, Grade 2, student book 4a, p. 16).

\subsection{Use of Students' own Input}

All thirteen textbooks included in our analysis emphasize in their teacher guidelines to let students explain in their own words what is happening in context situations, but (as already mentioned) none of them invite students to do this by using arrow language. All textbooks provide students with various assignments in the student books to produce problems themselves, the so-called "own productions" (Figure 14). Making use of students" own input by letting them come up with their "own constructions" of solution procedures is to a certain extent recognizable in all textbooks published from the 1990s on. These textbooks regularly present worked examples of different calculation strategies for particular addition or subtraction tasks, such as shown in Figure 12. These worked examples provide the opportunity to discuss multiple calculation procedures with students, yet this is not precisely the same as comparing and making use of students' own solution procedures-as emphasized in Proeve and TAL.

Make up your own problems that make 10. $1+9=10$ $11-1=10$
Make up and calculate. What might it say beneath the stain?

$$
\begin{aligned}
& 10+3=12-3= \\
& \text { How many problems can you make up? }
\end{aligned}
$$

Figure 14. Assignments for own productions in WiG1 (1980s, left, Grade 1, student book 1b, p. 60) and RR2 (2000s, right, Grade 1, Student book 3b, p. 29).

\section{Conclusions Study 2}

Study 2 showed that RME learning facilitators mentioned in the core documents including use of reality, models, and students' own input, are also present in the analyzed RME-oriented textbooks. However, regarding the use of particular learning facilitators, our findings are mixed-we found correspondences of RME-oriented textbooks with the RME core documents, as well as deviations. To provide an overview of our results from Study 2, we aggregated the textbooks findings per time period in Table 4 and placed them alongside the findings from Study 1.

In most cases, the use of learning facilitators provided by all or most RME-oriented textbooks corresponds with the intended use of these facilitators as indicated in the RME core documents. This applies to the use of the bus context and other context situations for providing meaning, the use of arrow language for symbolizing what is happening, and the use of the arithmetic rack and the empty number line. Further, the use and the disappearance of the one hundred square are in line with the core documents. Furthermore, there is a correspondence between the textbooks and core documents regarding the use of students' own input in the teaching-learning process in the form of their own wordings, their own productions of problems, and-although only to a certain extent-their own constructions of solution procedures. 
Table 4. RME learning facilitators and their intended use for early addition and subtraction in Wiskobas (W), Proeve (P), TAL (T), and RME-oriented textbooks per time period.

\section{RME Learning Facilitators and Intended Use} for Early Addition and Subtraction ${ }^{1}$
W P T

Textbooks

Use of reality

Bus context

- $\quad$ Providing meaning to both operations

- Introducing both operations in one situation

- Multiple calculations in one situation

Other context situations

- $\quad$ Providing meaning to both operations

Arrow language

- $\quad$ Symbolizing what happens

- $\quad$ Relating both operations

- $\quad$ Students using arrow language

Use of models

Segmented number line

- $\quad$ Positioning numbers by counting

- Supporting calculations

- $\quad$ Relating both operations

Empty number line

- $\quad$ Positioning numbers using number relations

- $\quad$ Supporting structured and varied calculations

One hundred square

- Offering exploratory activities

- $\quad$ Practicing both operations

Arithmetic rack

- $\quad$ Providing number images

- Supporting structured and varied calculations

Use of students' own input

- $\quad$ Students putting into words what is happening

- $\quad$ Students' own productions of problems

- Students' own constructions of solution procedures

जै

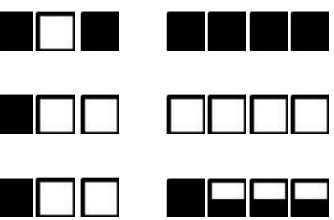

प⿴囗十口
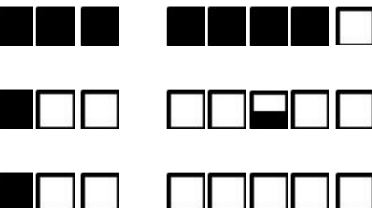

$\square \square \square \square \square \square$
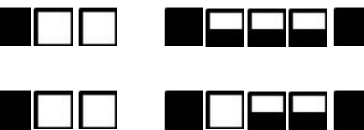

$\square \square \square \square \square \square \square$
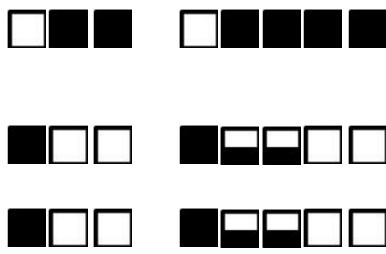

$\square \square \square \square \square \square$

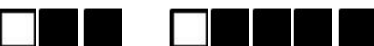

(1) 口а $\square \square \square$ $\square \square \square \square \square \square$

${ }^{1}$ Note: $\mathbf{\square}=$ present,$\square=$ absent, $\mathbf{C}=$ present in some, absent in other textbooks.

In several other cases, most or all textbooks deviate from the original intentions articulated by Wiskobas. This applies for the use of the bus context to introduce addition and subtraction in one situation, for the use of arrow language to relate addition and 
subtraction, and for letting students use arrow language to describe what is happening. These ways of using these learning facilitators, which are no longer mentioned in Proeve and TAL, are missing in the textbooks published after Proeve as well. In some textbooks, the use of the bus context to carry out multiple calculations in one situation is also not included.

A learning facilitator on which textbooks differ from Proeve and TAL is the segmented number line. While there is a change in the core documents from the segmented number line (in Wiskobas) to the empty number line (in Proeve and TAL), the textbooks released from the 1990s on (thus after the publication of Proeve) do not make this change. In addition to the empty number line, the segmented number line is still in use as well, mostly for positioning numbers and supporting calculations. Regarding relating addition and subtraction on the segmented number line, there is no overall pattern-some textbooks do this and others not.

\section{Overall Conclusions and Discussion}

The aim of this research was to trace how the RME reform evolved, and to unravel the relationship between the intentions of the RME reform and its implementation in textbooks. Our focus was on early addition and subtraction. We carried out two studies-one on the intended curriculum level as laid down in RME core documents, and one on the potentially implemented curriculum level in the form of RME-oriented textbooks.

In the study on RME as intended, we found that RME ideas on using reality, models, students' own input, and non-routine problems are steadily present in the RME core documents published over time. In these documents, we also found changes over time regarding particular learning facilitators and their intended use. Some of these changes can clearly be characterized as further refined concretizations of RME ideas. An example of this is the evolvement of the number line from a segmented to an empty one, which enables structured and varied calculation. These changes imply that reconceptualization of RME ideas not only took place on the overarching level of big ideas and teaching principles of RME, but also on the more detailed level of particular learning topics.

We also detected that some ideas that were emphasized in Wiskobas, the oldest RME core document, are surprisingly not present in the more recent ones Proeve and TAL. The most outspoken example of this is the use of learning facilitators for relating addition and subtraction to each other, which reflects the RME principle of intertwining related learning strands. This leaving out of ideas that earlier were present may be unintentional. We could not determine why these changes actually occurred, since the RME core documents did not provide arguments for these changes.

Our study on RME-oriented textbooks also led to mixed findings. We found that the RME-oriented textbooks generally correspond with the core RME documents on the point of the presence of learning facilitators, but at the same time we could not detect an overall pattern of alignment regarding the use of these learning facilitators. Thus, on the one hand, based on our findings we can conclude that over the course of fifty years the RME reform was and is still clearly present in Dutch primary school textbooks. On the other hand, this does not mean that these textbooks are fully in consonance with RME's intentions. We found several differences between the intended use of particular learning facilitators as indicated in the RME core documents, and the actual use of these facilitators as described in the textbooks. Something similar was already found in the study "Wiskobas in Methoden" [13]. In our study, we again found, over a long period of time, deviations from the original RME intentions in RME-oriented textbooks. A striking example of this is the use of arrow language. All textbooks that suggest its use apply it as a filling-in exercise, which is almost the opposite of using arrow language to describe what is happening, which is what was originally intended. Such findings clearly indicate that the mere presence of a particular RME feature in a textbook does not tell the whole story. To get a broader picture of how the RME reform was implemented in textbooks, the way in which it is interpreted in the textbooks has also to be taken into account. 
This brings us to the limitations of our research. Our design only covered the level of intended curriculum (the RME core documents) and the potentially implemented curriculum (the textbooks), but not the level of the implemented curriculum (the teaching and learning processes in school). This was beyond our scope and needs to be investigated as well to achieve a full understanding of the development and implementation process of RME. Of course, such a study should also not be restricted to early addition and subtraction but should include the full spectrum of mathematical content domains.

Although we are aware of the constraints of our research, we think we can conclude that it clearly shows how complicated the process is of generating and further developing ideas for how to teach mathematics and consequently getting them implemented in materials that teachers can use for their teaching. Our research has disclosed this process, which is in no way a straightforward route.

Author Contributions: Conceptualization, M.V.Z. and M.V.d.H.-P.; methodology, M.V.Z. and M.V.d.H.-P.; validation, M.V.Z. and M.V.d.H.-P.; formal analysis, M.V.Z. and M.V.d.H.-P.; investigation, M.V.Z.; resources, M.V.Z.; data curation, M.V.Z.; writing—original draft preparation, M.V.Z. and M.V.d.H.-P.; writing—review and editing, M.V.Z. and M.V.d.H.-P.; visualization, M.V.Z.; supervision, M.V.d.H.-P.; project administration, M.V.Z. All authors have read and agreed to the published version of the manuscript.

Funding: This research received no external funding.

Institutional Review Board Statement: Not applicable.

Informed Consent Statement: Not applicable.

Data Availability Statement: Not applicable.

Conflicts of Interest: The authors declare that they have no conflict of interest.

\section{References}

1. Valverde, G.; Bianchi, L.; Wolfe, R.; Schmidt, W.; Houang, R. According to the Book. Using Timss to Investigate the Translation of Policy into Practice through the World of Textbooks; Kluwer Academic Publishers: Dordrecht, The Netherlands, 2002.

2. Van den Akker, J. Curriculum perspectives: An introduction. In Curriculum Landscapes and Trends; Van den Akker, J., Kuiper, W., Hameyer, U., Eds.; Kluwer Academic Publishers: Dordrecht, The Netherlands, 2003; pp. 1-10.

3. Stein, M.; Remillard, J.; Smith, M. How curriculum influences student learning. In Second Handbook of Research on Mathematics Teaching and Learning; Lester, F., Ed.; Information Age Publishing: Charlotte, NC, USA, 2007; Volume 1, pp. $319-369$.

4. Dingman, S. Mathematics Textbooks and State Curriculum Standards: An Analysis of the Alignment between the Written and Intended Curricula. Ph.D. Thesis, University of Missouri, Columbia, MO, USA, 2007. [CrossRef]

5. Johansson, M. Textbooks in Mathematics Education. A Study of Textbooks as the Potentially Implemented Curriculum. Bachelor's Thesis, University of Technology, Luleå, Sweden, 2003.

6. Van Zanten, M.; Van den Heuvel-Panhuizen, M. Primary school mathematics in the Netherlands. The perspective of the curriculum documents. In International Perspectives on Mathematics Curriculum; Thompson, D., Huntley, M., Suurtamm, C., Eds.; Information Age Publishing: Charlotte, NC, USA, 2018; pp. 9-30.

7. Leung, F.; Graf, K.; Lopez-Real, F. (Eds.) Mathematics Education in Different Cultural Traditions. A Comparative Study of East Asia and the West. The 13th ICMI Study; Springer: New York, NY, USA, 2006. [CrossRef]

8. Schmidt, W.; McKnight, C.; Valverde, G.; Houang, R.; Wiley, D. Many Visions, Many Aims. A Cross-National Investigation of Curricular Intentions in School Mathematics; Kluwer Academic Publishers: Dordrecht, The Netherlands, 1997.

9. Furinghetti, F.; Karp, A. (Eds.) Researching the History of Mathematics Education. An International Overview; Springer: Dordrecht, The Netherlands, 2018. [CrossRef]

10. Karp, A.; Schubring, G. (Eds.) Handbook on the History of Mathematics Education; Springer: Dordrecht, The Netherlands, 2014.

11. Stanic, G.; Kilpatrick, J. (Eds.) A History of School Mathematics; NCTM: Reston, VA, USA, 2003.

12. Van den Heuvel-Panhuizen, M.; Drijvers, P. Realistic Mathematics Education. In Encyclopedia of Mathematics Education; Lerman, S., Ed.; Springer: Dordrecht, The Netherlands, 2020; pp. 521-525. [CrossRef]

13. De Jong, R. Wiskobas in Methoden Wiskobas in Textbooks. Ph.D. Thesis, Utrecht University, Utrecht, The Netherlands, 1986.

14. OEEC. New Thinking in School Mathematics; Organisation for European Economic Co-operation: Paris, France, 1961.

15. Bjarnadóttir, K. History of teaching arithmetic. In Handbook on the History of Mathematics Education; Karp, A., Schubring, G., Eds.; Springer: Berlin/Heidelberg, Germany, 2014; pp. 431-457. [CrossRef]

16. Bjarnadóttir, K. Influences from the 1959 Royaumont seminar. Proposals on arithmetic and algebra teaching at lower-secondary level in Iceland. In Researching the History of Mathematics Education. An International Overview; Furinghetti, F., Karp, A., Eds.; Springer: Berlin/Heidelberg, Germany, 2018; pp. 1-21. [CrossRef] 
17. Kilpatrick, J. The New Math as an international phenomenon. ZDM Math. Educ. 2012, 44, 563-571. [CrossRef]

18. Robitaille, D.; Travers, K. International Connections in Mathematics Education. In A History of School Mathematics; Stanic, G., Kilpatrick, J., Eds.; NCTM: Reston, VA, USA, 2003; pp. 1491-1508.

19. Treffers, A. Wiskobas and Freudenthal. Realistic mathematics education. Educ. Stud. Math. 1993, 25, 89-108. [CrossRef]

20. CMLW. Commissie Modernisering Leerplan Wiskunde Commission Modernization Mathematics Curriculum. Euclides 1961, 37, 144-151.

21. Treffers, A. Wiskobas Doelgericht Wiskobas Goal-Directed. Ph.D. Thesis, IOWO, Utrecht University, Utrecht, The Netherlands, 1978.

22. Treffers, A. Three Dimensions. A Model of Goal and Theory Description in Mathematics Instruction-The Wiskobas Project; Reidel Publishing Company: Dordrecht, The Netherlands, 1987.

23. Freudenthal, H. Major problems of mathematics education. Educ. Stud. Math. 1981, 12, 133-150. [CrossRef]

24. Freudenthal, H. Why to teach mathematics so as to be useful. Educ. Stud. Math. 1968, 1, 3-8. [CrossRef]

25. Freudenthal, H. Mathematics as an Educational Task; Reidel Publishing Company: Dordrecht, The Netherlands, 1973.

26. Van den Brink, J. Bijna noemen Almost mention it. Wiskobas Bull. 1973, 3, 129-131.

27. Van den Brink, J. Realistisch Rekenonderwijs aan Jonge Kinderen; [Realistic Mathematics Education for Young Students]; Utrecht University: Utrecht, The Netherlands, 1989.

28. Wijdeveld, E. Zich realiseren To realize. In De Achterkant van de Möbiusband; Pieters, S., Ed.; IOWO: Utrecht, The Netherlands, 1980; pp. 23-26.

29. Van den Heuvel-Panhuizen, M. Assessment and Realistic Mathematics Education; CD- $\beta$ Press/Freudenthal Institute, Utrecht University: Utrecht, The Netherlands, 1996.

30. Freudenthal, H. Revisiting Mathematics Education; Kluwer Academic Publishers: Dordrecht, The Netherlands, 1991.

31. Van Zanten, M. Students' own productions and own constructions-Adri Treffers' contributions to Realistic Mathematics Education. In European Traditions in Didactics of Mathematics, ICME-13 Monographs; Blum, W., Artigue, M., Mariotti, M., Sträßer, R., Van den Heuvel-Panhuizen, M., Eds.; Springer Nature: Cham, Switzerland, 2019; pp. 67-73.

32. Treffers, A.; De Moor, E.; Feijs, E. Proeve van een Nationaal Programma voor het Reken-Wiskundeonderwijs op de Basisschool 1. Overzicht Einddoelen; Design of a National Program for Mathematics Education in Primary School 1. Overview of Goals; Zwijsen: Tilburg, The Netherlands, 1989.

33. Van den Heuvel-Panhuizen, M. Realistic mathematics education in the Netherlands. In Principles and Practices in Arithmetic Teaching. Innovative Approaches for the Primary Classroom; Anghileri, J., Ed.; Open University Press: Maidenhead, Berkshire, UK, 2001; pp. 49-63.

34. Janssen, J.; Van der Schoot, F.; Hemker, B.; Verhelst, N. Balans van het Reken-Wiskundeonderwijs aan het Einde van de Basisschool 3; Balance of Mathematics Education at the End of Primary School 3; Cito: Arnhem, The Netherlands, 1999.

35. Janssen, J.; Van der Schoot, F.; Hemker, B. Balans van het Reken-Wiskundeonderwijs aan het Einde van de Basisschool 4; Balance of Mathematics Education at the End of Primary School 4; Cito: Arnhem, The Netherlands, 2005.

36. Royal Netherlands Academy of Sciences (KNAW). Rekenonderwijs op de Basisschool; Mathematics Education in Primary School; KNAW: Amsterdam, The Netherlands, 2009.

37. Van den Heuvel-Panhuizen, M. Reform under attack-Forty years of working on better mathematics education thrown on the scrapheap? No way! In Shaping the Future of Mathematics Education: Proceedings of the 33rd Annual Conference of the Mathematics Education Research Group of Australasia; Sparrow, L., Kissane, B., Hurst, C., Eds.; MERGA: Fremantle, Australia, 2010 ; pp. 1-25.

38. Van Zanten, M.; Van den Heuvel-Panhuizen, M. Freedom of design: The multiple faces of subtraction in Dutch primary school textbooks. In Mathematics Curriculum in School Education; Li, Y., Lappan, G., Eds.; Springer: Dordrecht, The Netherlands, 2014; pp. 231-259. [CrossRef]

39. De Jong, R.; Treffers, A.; Wijdeveld, E. (Eds.) Overzicht van Wiskundeonderwijs op de Basisschool. Leerplanpublikatie 2; Overview of Mathematics Education in Primary School. Curriculum Document 2; IOWO: Utrecht, The Netherlands, 1975.

40. Treffers, A.; De Moor, E. Proeve van een Nationaal Programma voor het Reken-Wiskundeonderwijs op de Basisschool 2. Basisvaardigheden en Cijferen; Design of a National Program for Mathematics Education in Primary School 2. Basic Operations and Algorithmic Calculation; Zwijsen: Tilburg, The Netherlands, 1990.

41. Treffers, A.; Van den-Heuvel-Panhuizen, M.; Buys, K. (Eds.) Jonge Kinderen Leren Rekenen. Tussendoelen Annex Leerlijnen; Young Children Learn Mathematics. Intermediate Attainment Targets and Teaching-Learning Trajectories; Wolters-Noordhoff: Groningen, The Netherlands, 1999.

42. Van den Heuvel-Panhuizen, M. (Ed.) Children Learn Mathematics. A Teaching-Learning Trajectory with Intermediate Attainment Targets for Calculation with Whole Numbers in Primary School; Freudenthal Institute, Utrecht University: Utrecht, The Netherlands, 2001.

43. Kolovou, A.; Van den Heuvel-Panhuizen, M.; Bakker, A. Non-routine problem solving tasks in primary school mathematics textbooks. A needle in a haystack. Mediterr. J. Math. 2009, 8, 31-68.

44. Van Zanten, M.; Van den Heuvel-Panhuizen, M. Opportunity to learn problem solving in Dutch primary school mathematics textbooks. ZDM Math. Educ. 2019, 50, 827-838. [CrossRef] 